УДК 373.5.016:94(477)(043.3)

Режим доступу до журналу: http://www.journal.iitta.gov.ua

Гаврилюк Жанна Миколаївна, учитель-методист гімназії «Діалог», здобувач наукового ступеня кафедри методики навчання суспільних дисциплін та гендерної освіти НПУ імені М. П. Драгоманова, м. Київ, e-mail: shannusia@i.ua

\title{
ВИКОРИСТАННЯ ІКТ У ВИВЧЕННІ КУЛЬТУРОЛОГІЧНИХ ТЕМ У КУРСІ ІСТОРІї УКРАЇНИ
}

\begin{abstract}
Анотація
Актуальність матеріалу, викладеного у статті, обумовлена провідною метою застосування IКТ на уроці історії для досягнення більш глибокого осмислення навчального культурологічного матеріалу, образного сприйняття, посилення емоційного впливу історії на особистість учня, його «занурення» в досліджувану епоху, сприяння впровадженню новітніх інформаційних технологій у процеси управління освітою. Потужний потік нової інформації, застосування комп'ютерної технології, поширення різних технічних засобів накладають великий вплив на виховання підростаючого покоління і їхнє сприйняття навколишнього світу. Вимога часу i потреба учнів у сучасних інформаційних технологіях потребує створення мультимедійного продукту, який би відповідав вимогам сучасності й забезпечував високий рівень засвоєння учнями програмового матеріалу предметів суспільного циклу.
\end{abstract}

Ключові слова: мультимедійні засоби навчання, комп’ютерна грамотність, ІКТ в освіті, культурологічні теми, полікультурність.

Постановка проблеми. У Національній доктрині розвитку освіти в Україні зазначено: «пріоритетом розвитку освіти $\epsilon$ впровадження сучасних IКТ, що забезпечують подальше удосконалення навчально-виховного процесу, доступність та ефективність освіти, підготовку молодого покоління до життєдіяльності в інформаційному суспільстві» [1]. Сучасні інформаційні технології відіграють значну роль у формуванні ціннісних орієнтацій сучасної молоді. Медіа освіта орієнтована на підготовку молоді до життя в нових інформаційних умовах, до повноцінного сприймання різноманітної інформації, оволодіння способами спілкування на основі сучасних інформаційних технологій, уміння критично осмислювати. Усі ці процеси $є$ 
взаємопов'язаними між собою; саме тому вони потребують особливої уваги тих, хто нині приймає рішення щодо покращення якості освіти [2].

Використання комп'ютерних технологій покликане розв'язати завдання розширення інтелектуальних можливостей учня. Комп'ютер застосовується як самий досконалий інформаційний засіб на уроках суспільно-гуманітарних дисциплін поряд 3 використанням книжки, телевізора, DVD плеєра. Електронні навчальні посібники, створені на базі мультимедія, відеофрагменти та відеофільми мають сильний вплив на пам'ять і уяву, полегшують процес запам'ятовування, дозволяють зробити урок більш цікавим і динамічним, «занурити» учня в обстановку якої-небудь історичної епохи, створити ілюзію співприсутності, співпереживання, сприяють становленню об'ємних і яскравих уявлень про минуле [3].

Система сучасної освіти веде до зміни пріоритетів у діяльності вчителя: не навчити, а створити умови для самостійного творчого пошуку знань учнями. Інформаційно-комунікаційні технології стають необхідним компонентом уроку історії в сучасній школі й сучасний вчитель - це високопрофесійний педагог, що використає у своїй роботі інформаційні технології.

Аналіз останніх досліджень і публікацій. Питання методики викладання історії засобами комп'ютерних технологій в історико-методичній літературі, за великим рахунком, практично не розглянуті, за винятком певної кількості статей у педагогічній пресі 3 описом конкретного досвіду окремих учителів. Відсутні в літературі також і праці, пов'язані з розробкою комп'ютерних навчальних посібників або програм з історії.

Використання на уроці технічних засобів навчання як окрему педагогічну проблему достатньо глибоко і повно розглядали М. I. Аппарович, С. В. Думин, М. Г. Заволока, А. І. Зільберштейн, Б. Н. Полозов, Д. І. Полторак, В. М. Попов, Л. М. Прессман та ін. Ними детально розроблено дидактичні й методичні підходи до застосування технічних засобів навчання у різних навчальних предметах, у тому числі на уроках історії.

Питанням застосування комп'ютера в навчально-пізнавальному процесі, незважаючи на певну новизну проблеми, уже приділено достатньо уваги в науковій літературі: Е. І. Виштинецький, П. А. Гевал, В. І. Гриценко, А. С. Демушкін, 
О. М. Довгялло, Л. С. Ісакова, А. І. Кириллов, А. О. Кривошеєв, Ю. І. Машбиць, А. Я. Савельєв, Н. А. Слівіна, А. В. Соловов та ін. [5].

Формулювання цілей статті. Проблемою сьогодення є відсутність методики застосування програмних засобів в курсі історії, що змушує вчителів самостійно, шляхом випадкового підбору створювати власну методику, часто без врахування дидактичної і методичної доцільності. Тому важливим нині є розгляд сучасного стану запровадження IКТ у навчальні процеси, і вироблення певних рекомендацій з метою їх реалізації.

Виклад основного матеріалу дослідження. Українська освіта нині стоїть на порозі значних зрушень у розвитку і запровадженні інноваційних технологій для покращення загальної якості освіти. Важливим напрямом розбудови для українських освітян є сфера інформаційної грамотності і запровадження ІКТ у всі освітні процеси, починаючи від процесу навчання до процесів управління освітою і моніторингу освітніх результатів. Велика увага приділяється розробці стандартів IКТ в освіті завдяки інтеграції України у загальносвітові освітні процеси і мережі [3].

Вивчення культурологічних тем в курсі історії України передбачає виховання в дусі толерантності, прищеплення культури миру, свідомості того, що прагнення до етнічної ідентичності має розглядатися як джерело загального духовного багатства, а не загрози національним цінностям й існуванню окремих народів. Так, у доповіді міжнародної комісії ЮНЕСКО про глобальні стратегії розвитку освіти в ХХІ столітті підкреслюється, що одна з найважливіших функцій сучасної школи — навчити людей жити разом, допомогти їм перетворити існуючу взаємозалежність держав і етносів у свідому солідарність. 3 цією метою освіта має сприяти тому, щоб, з одного боку, людина усвідомила своє коріння і тим самим могла визначити місце, яке вона посідає у світі, i, з іншого, - прищепити їй шанобливе ставлення до інших культур [2].

Полікультурність розглядається як дидактичний принцип виховувати учнів у дусі міжкультурної толерантності, культурного плюралізму, багатокультурного балансу в змісті навчального процесу. Разом $з$ тим, сучасний етап розвитку світової Цивілізації пов’язують 3 інформаційною революцією, розвитком інформаційнокомунікаційних технологій (IКТ), які радикально змінюють суспільне життя. Живучи у світі високих інформаційних технологій, потребою суспільства є залучення всіх до процесу інформатизації. Потреба людини зайняти своє місце в соціумі, призводить до 
необхідності застосування сучасних інформаційних технологій на практиці. Уміння знаходити інформацію за найменших втрат часу — життєва необхідність суспільства, де кількість інформації протягом 5 років подвоюється.

Дуже високо оцінили можливості інформатизації учителі гуманітарного циклу, у тому числі й історії. Освітні ресурси нового покоління дозволяють на якісно новому рівні викладати історію, використовуючи найрізноманітніші методи і технології, а завдяки поєднанню традиційних педагогічних технологій та IКТ вдається зробити урок більш насиченим і цікавим.

Які можливості відкриває перед учителем історії використання ІКТ? Це, передусім, можливість для учителя мати під рукою величезну кількість ілюстративного матеріалу, а, головне, дуже швидкий доступ до нього дасть змогу готувати для школярів ресурси, що містять необхідні дані, ймовірність для педагога створювати самостійно тести для перевірки засвоєння певного матеріалу, безпосереднє ознайомлення вчителя 3 новинками методичної літератури. Уроки культури є найбільш благодатні для використання наочних засобів навчання для закріплення знань; завжди можна знайти застосування альбомам, виставковим каталогам, звукозаписам, художнім фільмам, слайдам [3].

Дуже перспективним і дієвим є використання презентацій, що поєднують теоретичний обсяг матеріалу з ілюстративним. Активне впровадження інформаційних технологій у навчальний процес викликало появу таких засобів навчання як електронні підручники, що мають посилання на інші посилання в Інтернеті, засоби автоматичного контролю засвоєння знань, адреси Інтернет-бібліотек.

Такі уроки вимагають знання вчителем індивідуальних особливостей учнів, їхніх інтересів, а також атмосфери довіри між учителем і учнями, педагогіки співробітництва; створити умови, щоб учні замислились, вслухались, побачили, зрозуміли, співставили, проаналізували, зробили висновки, висловили власну точку зору, зуміли відстояти свою позицію, проявивши толерантність до думки інших, ввійшли у світ мистецтва, у світ краси, величі, благородства, спробували зрозуміти i осягнути задум художника, письменника, поета, значення наукового відкриття, відчули чарівність музики. Слайди, репродукції, записи духовного співу, картинки природи, репродукції біблейських сюжетів з гравюр - допоможуть зробити урок 
таким, що більш запам'ятовується. Необхідно пам'ятати про те, що найбільш високою ефективністю для запам'ятовування служить поєднання наочності зі словом учителя.

Сучасний світ уже не можна уявити без комп’ютера. Тому застосування комп'ютерних програм у викладанні історії культури дають викладачеві нові, гнучкіші можливості подання матеріалу, забезпечують абсолютно новий підхід до спілкування з учнями, активізують різні види діяльності учнів, розвивають в них уміння самостійно вивчати й аналізувати матеріал. Використання комп'ютера на сучасному етапі дозволяє учителеві легко варіювати глибину i складність культурологічного матеріалу, що вивчається на уроці.

Ми пропонуємо використовувати досвід застосування комп'ютерних програм у викладанні історії культури, які дають викладачеві нові, гнучкіші можливості подання матеріалу, забезпечують абсолютно новий підхід до спілкування з учнями, активізують різні види діяльності учнів, розвивають у них уміння самостійно вивчати й аналізувати матеріал. Дозволяють учителеві легко варіювати глибину і складність теми уроку, що вивчається. Сучасні комп'ютерні програми (Paint, Cakewalk, ACID Pro, Flash MX та ін.) дозволяють створювати графічні й анімаційні екранні образи 3 використанням виразної лінії, форми, об'єму, кольору, руху, музики, оповідання. Вони надають учням можливість експериментувати з різними варіантами зображень $\mathrm{i}$ музичних фрагментів, синтезувати різноманітні види аудіовізуальної інформації. Процес комп'ютерного моделювання, заснований на сучасних технологіях, підвищує мотивацію учнів і створює атмосферу творчості. Водночас комп'ютер є не лише потужним пізнавальним засобом для вивчення художньої культури, але й інструментом освоєння теоретичних основ образотворчого і музичного мистецтва, формування художнього смаку, розвитку фантазії і творчих здібностей.

Найпотужніші можливості мають електронні підручники i посібники: забезпечуючи урок відео, музичними художніми і голосовими фрагментами, дають можливість учням зануриться у світ музики, живопис і архітектуру, відчути твір мистецтва, бути "присутнім" у художній галереї, на опері, в музеї і біля архітектурних пам'яток; відчути специфіку того часу, коли створювалися ці твори; здійснити занурення в певну історичну епоху.

\section{Основні методичні рекомендації для учнів із самостійної підготовки}


1. Для підготовки і виконання завдань кожному учневі необхідно створити на Робочому столі комп'ютера в комп'ютерному класі індивідуальну теку з посиланнями i коментарями (файл *.doc) на інформаційні i мультимедія ресурси 3 культурологічного матеріалу для створення загального методичного банку даних, куди до списку інформаційних ресурсів повинні входити:

- бази даних;

- електронні довідники, енциклопедії, словники;

- портали і сайти з художньої культури України певного періоду;

- текстові і медіябібліотеки;

- сайти музеїв і галерей;

- сайти туристичних компаній.

2. До списку мультимедія-ресурсів на електронних носіях повинні входити:

- енциклопедії:

- збірки;

- хрестоматії;

- програми;

- розвивальні ігри.

3. Аналіз кожного типу інформаційного і мультимедія-ресурсу повинен включати:

- інформацію про вихідні дані видання або точне місцезнаходження ресурсу (основна Web-aдреса, якщо ресурс самостійний, або Web-адреса головної сторінки 3 посиланнями на місце розташування ресурсу);

- короткий опис структури ресурсу в цілому;

- переваги і недоліки навігації;

- переваги і недоліки естетичного оформлення ресурсу;

• оцінку змістовної глибини і якості матеріалів, що представляються;

- можливості інтерактивності ресурсу.

Особливостями використання IКТ є можливості застосування на різних етапах навчального процесу (пояснення нового матеріалу, закріплення вивченого, проміжний і підсумковий контроль, самостійна робота, творча i науково-дослідна діяльність учнів). Проте вчителеві слід пам'ятати, що будь-який навчальний процес базується на використанні педагогічних технологій, тому IКТ мають набути педагогічного змісту. Внаслідок використання IКТ на уроках історії: 
- збільшується можливість використання наочних матеріалів;

- підвищується ефективність роботи учителя і учня;

- встановлюється міжпредметний зв'язок 3 основами інформатики та обчислювальної техніки;

- стає можливою організація проектної діяльності учнів під керівництвом учителя, спрямована на створення електронних навчальних продуктів;

- змінюється ставлення до комп'ютера: учні починають сприймати його як інструмент для роботи в будь-якій галузі людської діяльності, а не як цікаву іграшку [5].

Отже, завдяки поєднанню традиційних педагогічних технологій та IКТ вдається зробити урок більш насиченим i цікавим, бо використання різних комп'ютерних програм на уроках культури забезпечить ефект «присутності» в художній галереї, музеї і музичній виставі, біля архітектурних пам'яток тощо; допоможе відчути специфіку того часу, коли створювалися ці твори; дозволить здійснити занурення в певну історичну епоху, а також глибоко і об'ємно систематизувати знання учнів 3 питань культури. Усе це сприятиме якісному підвищенню рівня навчання і виховання учнів.

У зв'язку з цим зазначимо, що сучасний рівень комп’ютерної підготовки дозволяє вчителям самостійно створювати наочність і залучати до цього учнів. Саме для цього були створені такі програми, як (MS Word, MS Power Point, CorelDraw).

Учитель має створити умови для: а) формування навичок візуальної комунікації, зокрема, здатність розглядати твори живопису; б) уміння бачити окремі деталі; в) розуміти їх зміст і значення; сприймати деталі творів у взаємодії; г) вміти відрізняти художні особливості; г) розширювати уявлення про епоху, усвідомлюючи процес створення цінностей, що відповідають їй.

Н. Дементієвська відносить до переваг мультимедійної презентації можливість: використання для індивідуального перегляду на комп'ютері; адаптації під особливості сприйняття учнями навчального матеріалу; самостійного визначення тривалості процесу навчання; зміни, доповнення чи зменшення обсягу змістової інформації [3].

Найяскравіше себе зарекомендували презентації як вчительські (під час подання нового матеріалу), так і учнівські (під час перевірки домашнього завдання, захисту проекту). Презентація, як вид наочності, може використовуватися для 
підвищення мотивації навчальної діяльності учнів. Нині у викладачів з'явилася можливість самостійно створювати навчальні медія-продукти з подальшим їх записом на компакт-диски. Авторський продукт простий у застосуванні, його освоєння не вимагає великих тимчасових витрат i дозволяє за лічені години створити мультимедійну підтримку навчальної діяльності. Проте під час підготовки електронних навчальних продуктів необхідно уникнути таких, наприклад, недоліків, як: погана якість інформації, що презентується; віддзеркалення суто особистих поглядів творців, що не завжди відповідають сучасній теорії і практиці освіти; створення ідентичних електронних копій традиційних підручників; неефективність $\mathrm{i}$ примітивізм використання можливостей персонального комп'ютера. О. Мокрогуз наводить деякі адреси сайтів, на яких розміщені великі колекції презентацій: http://www.rusedu.ru/subcat_32.html — apxiв навчальних програм і презентацій, на якому розміщено більше 100 презентацій; http://som.fio.ru/subject.asp?id=10000189 — сайт «На допомогу вчителю». На вказаній сторінці розміщена велика кількість презентацій: 382 презентації О. Чернова, 134 презентації О. Худобця, 88 презентацій інших учителів; http://www.pedagog. by/prist.html — сайт «Планування та презентації уроків» [4].

Разом 3 тим, учений зазначає, що аналіз англомовних сайтів, таких як www.besthistorysites.net, ～Www.pptpalooza.net, multimedialearning.org, www.schoolhistory.co.uk та сайтів окремих навчальних закладів засвідчив наявність значної кількості готових презентацій, виготовлених як учителями, так і учнями, які використовуються у навчальному процесі. Практично всі презентації не мають рекомендацій щодо їх використанню у навчальному процесі.

Слушним бачиться концепція Ю. Троїцького. Автор методики говорить про те, що учня необхідно поставити в позицію творця предметної реальності, перейти від репродукції реальності до творчості.

Основним засобом пізнання історичної дійсності в концепції Троїцького виступає документально-методичний комплекс.

Документально-методичний комплекс - це не просто документи тієї чи іншої епохи, хроніка, фото, які вивчають школярі, а й підібрані ключові тексти; - це система запитань і завдань, складених проблемно, тобто так, які не мають однозначно універсальних відповідей і які передбачають роздуми учнів [6; с. 2]. 
Як учитель може використати документально-методичний комплекс? Написати на дошці, фліп-чарті. Але краще всього ж, безумовно, використати ресурси IКТ.

У цілому використання в роботі з джерелами комплексу допомагає вчителю розв'язати такі завдання:

- спонукання історичної самосвідомості учня;

- використання тексту як джерела історичного знання;

- освоєння дітьми основних рольових позицій через залучення до інтерпретації джерела, розуміння історичного часу, простору, зближення учня і досліджуваної епохи. Щоб виробити власну позицію, учень лише знайомитися зі способами розуміння джерел, згідно існуючих типів мислення, що в кінцевому підсумку стимулює використання розумової активності учнів.

Отже, документально-методичний комплекс дозволяє доповнити підручник і розвиває індивідуальний стиль мислення дитини. Освітня технологія Ю. Л. Троїцького спрямована на розвиток не стільки відтворювальних здібностей учнів, стільки на розвиток предметної діяльності і творчих здібностей дитини.

Важливим ресурсом для проведення уроків є використання освітніх веб-сайтів, які $є$ джерелом відео-, аудіо- та ілюстративного матеріалу. На формування ж комунікативних компетенцій впливає створення телекомунікаційних проектів. Він доречний у класах, де вже сформований певний ступінь самостійної роботи, (у нашому випадку 8-9 класи). Цей метод ефективно спрацьовує у процесі роботи над проблемними навчальними ситуаціями, розв’ язання яких передбачає як використання різноманітних методів і засобів навчання, так й інтегрування знань, умінь та навичок 3 різних галузей науки, технології, творчості.

Висновки. Огляд ситуації використання ІКТ у вивченні культурологічних тем дає нам підстави говорити про останні тенденції й окреслити певні перспективи.

- Важливість розвитку і використання в системі освіти нових, особистісноорієнтованих інформаційно-комунікаційних технологій $\epsilon$ незаперечною у контексті швидкоплинних процесів розвитку технологій, виробництва, змін у економіці й соціальній сфері життя країни.

- Потужний потік нової інформації, застосування комп'ютерної технології, поширення різних технічних засобів накладають великий вплив на виховання підростаючого покоління і їх сприйняття навколишнього світу. 
- Важливим вбачається проведення внутрішніх серйозних досліджень застосування IКТ у навчальних закладах і рівня володіння IКТ навичками вчителів.

- Комп’ютеризація, технотронні технології, сенсаційні відкриття, кардинальна трансформація інформаційного простору якісно змінили всі сфери суспільного життя. Саме тому інноваційне мислення й інноваційна діяльність набули надактуального значення для всіх сфер життєдіяльності, а особливо для освіти і педагогіки. Бо саме через освіту, у першу чергу, можна підготувати людину 3 інноваційним типом мислення, культури і здатності до інноваційної діяльності. Без цього ні людина не буде конкурентоспроможною, ні країна не буде успішною в сучасних умовах розвитку.

- Вимога часу і потреба учнів у сучасних інформаційних технологіях потребує створення мультимедійного продукту, який би відповідав вимогам сучасності й забезпечував високий рівень засвоєння учнями програмового матеріалу предметів суспільного циклу. Враховуючи те, що в масштабах України ще недостатньо таких матеріалів, важливо, щоб учитель, працюючи над темами уроку, намагався стати автором власних мультимедійних продуктів, які б відповідали не лише вимогам програм, але й методиці викладання і індивідуальному стилю спілкування учителя з учнями.

- Реалії сьогодення, процес оновлення змісту, форм і методів організації вищої педагогічної освіти потребують удосконалення системи професійної підготовки науково-педагогічних кадрів й актуалізують проблему ретроспективного осмислення становлення й розвитку системи підготовки фахівців у наукових школах України, що сприятиме виваженим підходам до вироблення сучасних освітніх концепцій.

\section{Список використаних джерел}

1. Державна програма «Інформаційні та комунікаційні технології в освіті і науці на 2006-2010 роки», затверджена постановою Кабінету Міністрів від 7 грудня 2005 p. № 1153. [Електронний ресурс]. - Режим доступу : http://zakon2.rada.gov.ua/laws/show/1153-2005-\%D0\%BF. 
2. Всесвітня доповідь ЮНЕСКО про комунікацію та інформацію в 19992000. [Електронний ресурс]. http://www.polpred.com/free/unesco/2.htm.

3. Дементієвська H. П. Проектування, створення та використання навчальних мультимедійних презентацій як засобу розвитку мислення учнів [Електронний ресурс] / Н. П. Дементієвська, Н. В. Морзе // Інформаційні технології і засоби навчання. Електронне наукове фахове видання. — 2007. — № 1 (2). — Режим доступу : http://www.ime.edu-ua.net/em2/emg.html.

4. Мокрогуз О. П. Методика застосування мультимедійних презентацій у навчанні історії старшокласників [Електронний ресурс] // Педагогіка, методика викладання історії : матеріали Міжнар. фестивалю пед. інновацій. - Режим доступу : http://oipopp.edsp.net/component/option,com_metod/metodTask,metodDetails/catid,1053/ metodId,1164/Itemid,51/.

5. Неумитий $B . M$.Особливості використання IКТ у навчальному процесі загальноосвітньої школи(на прикладі уроків історії) [Електронний ресурс]. — Режим доступу : http://oipopp.ed-sp.net/content/view/2112/15/.

6. Троӥцький Ю. Л. Нова технологія історичної освіти // Історія. Щотижневий додаток до газети «Перше вересня». — 1994. — № 45. — С. 2-5.

\section{ИСПОЛЬЗОВАНИЕ ИКТ В ИЗУЧЕНИИ КУЛЬТУРОЛОГИЧЕСКИХ ТЕМ В КУРСЕ ИСТОРИИ УКРАИНЫ}

Гаврилюк Жанна Николаевна, учитель-методист гимназии «Диалог», соискатель ученой степени кафедры методики обучения общественных дисциплин и гендерного образования НПУ имени М. П. Драгоманова, e-mail: shannusia@i.ua

\section{Аннотация}

Актуальность материала, изложенного в статье, обусловлена ведущей целью применения ИКТ на уроке истории для достижения более глубокого осмысления учебного культурологического материала. А так же образного восприятия, усиления эмоционального воздействия истории на личность ученика, его «погружение» в изучаемую эпоху, содействии внедрению новейших информационных технологий в процессы управления образованием. Мощный поток новой информации, применение компьютерной технологии, распространение различных технических средств 
накладывают большое влияние на воспитание подрастающего поколения и их восприятие окружающего мира. Требование времени и потребность учащихся в современных информационных технологиях требует создания мультимедийного продукта, который бы отвечал требованиям современности и обеспечивал высокий уровень усвоения учащимися программного материала предметов общественного цикла.

Ключевые слова: мультимедийные средства обучения, компьютерная грамотность, ИКТ в образовании, культурологические темы, поликультурность.

\section{ICT USING DURING STUDYING CULTUROLOGICAL THEMES IN COURSE OF HISTORY OF UKRAINE}

Zhanna M. Gavrylyuk, teacher, gymnasium "Dialogue", candidate for a degree, Department of training methods of social disciplines and gender education, National Pedagogical Dragomanov University, Kyiv, e-mail: shannusia@i.ua

\section{Resume}

Relevance of material, presented in the article, due to the lead of using ICT on the lessons of History to achieve a deeper understanding of educational cultural material, pattern perception, strengthening the emotional impact of history on the personality of student, his "immersion" in the investigated period, facilitating the introduction of advanced information technologies in the management education. A powerful stream of new information, the application of computer technology, the spread of various hardware impose great influence on the upbringing of the young generation and their perception of the world. The requirement of time and student needs in today's information technology requires the creation of a multimedia product which would meet the requirements of the modern world and provide a high level of students learning program material objects of social cycle.

Keywords: multimedia training, computer literacy, ICT in education, cultural topics, multiculturalism. 